\title{
KAJIAN PIDANA KERJA SOSIAL DITINJAU DARI SEGI SOSIOLOGI HUKUM
}

\author{
Bheti Widyastuti \\ Magister Ilmu Hukum Universitas Sebelas Maret Surakarta \\ Jln. Ir Sutami No. 36 A, Pucangsawit, Jebres, Surakarta \\ E-mail: bheti84@gmail.com
}

\begin{abstract}
In the application of Criminal Law in Indonesia, it uses a model of imprisonment. Imprisonment penalties are often used because they are considered effective in providing a deterrent effect on criminals. However, along with the development of the times, imprisonment sanctions are considered not to prioritize the human side concerning the right to freedom for every human being. In the Draft Draft Criminal Code 2017 alternative sanctions were prepared. One of the alternative sanctions that will be discussed by the author is social work criminal sanctions. Social work criminal sanctions are considered in accordance with current criteria which prioritize the human side and provide direct moral learning to criminals. So that the author here aims to discuss the application of social work criminal sanctions in Indonesia from a criminal law perspective and the application of social work sanctions from a sociological legal perspective.
\end{abstract}

Keywords: social work criminal sanctions, criminal law, sociology of law.

\begin{abstract}
Abstrak
Dalam penerapannya Hukum Pidana di Indonesia menggunakan model penjatuhan sanksi pidana penjara. Sanksi pidana penjara sering kali digunakan karena dinilai efektif dalam memberikan efek jera bagi pelaku kejahatan. Namun seiring dengan perkembangan zaman sanksi pidana penjara dinilai tidak mengedepankan sisi kemanusian yang menyangkut hak merdeka bagi setiap manusia. Dalam Draft RUU KUHP 2017 disusunlah alternatif sanksi. Salah satu alternatif sanksi yang akan dibahas oleh penulis adalah sanksi pidana kerja sosial. Sanksi pidana kerja sosial dinilai sesuai dengan kriteria zaman saat ini yang lebih mengedepankan sisi kemanusiaan dan memberikan pembelajaran moral secara langsung kepada pelaku kejahatan. Sehingga penulis disini bermaksud untuk membahas penerapan sanksi pidana kerja sosial di Indonesia dari perspektif hukum pidana dan penerapan sanksi kerja sosial dari perspektif sosiologi hukum.
\end{abstract}

Kata kunci : sanksi pidana kerja sosial, hukum pidana, sosiologi hukum.

\section{A. Pendahuluan}

KUHP yang digunakan oleh bangsa Indonesia saat ini harus diperbaharui. Menurut pendapat Sudarto, ada tiga argumen mengapa dibutuhkan pembaharuan terhadap KUHP. Ketiga alasan tersebut didasarkan pada alasan politis, praktis, dan sosiologis:

1. Berdasarkan alasan politis, sudah saatnya bangsa Indonesia memiliki kitab hukum pidana yang merupakan buatan dari anak bangsa sendiri, seperti yang kita ketahui bahwa KUHP yang saat ini digunakan adalah buatan Belanda. 
2. Berdasarkan alasan praktis, KUHP yang saat ini digunakan merupakan berbahasa belanda, dan pemerintah Indonesia beserta DPR selaku pembuat kebijakan hukum Indonesia tidak pernah mengeluarkan terjemahan KUHP secara resmi, hal ini yang membuat penafsiran hakim berbeda satu dengan yang lain.

3. Berdasarkan alasan sosiologis, sanksi-sanksi pidana yang terdapat dalam KUHP sudah tidak mencerminkan kemajuan beradaban, hal ini dikarenakan KUHP kita masih mengandalkan hukuman badan (hukuman penjara) sebagai hukuman utama. Padahal di negara eropa sendiri sudah tidak lagi mengandalkan hukuman penjara, mereka lebih mengutamakan hukuman pidana sosial dibandingkan hukuman penjara.

Konsep hukuman pidana di Indonesia pada dewasa ini memiliki tujuan untuk melindungi warga negara atau melindungi kepentingan umum maupun negara dan melindungi Hak Asasi Manusia dari tindak pidana atau penyalahgunakan hak yang dapat merugikan perseorangan, anggota masyarakat, kepentingan negara serta mencegah agar pemegang kekuasaan agar tidak bertindak otoriter pada perseorangan maupun warga negara. Bukan rahasia lagi bahwa apabila rakyat jelata menuntut keadilan dan hukuman melalui proses peradilan terhadap perbuatan yang menimbulkan tindak pidana akan terganjal kendala, yaitu hukum pidana formiil, hukum pidana materiil, dan filsafat hukum pidana dan sanksi pidana yang ada memang tidak menggunakan konsep hukum responsif yang mana seharusnya dapat memenuhi kebutuhan masyarakat. ${ }^{1}$ sudah saatnya pemerintah Indonesia merumuskan sanksi pidana kerja sosial sebagai terobosan, sanksi pidana kerja sosial yang dikenakan kepada terpidana telah mencapai hal-hal yang bersifat pembinaan dan mencegah terpidana terkena dampak buruk akibat dipenjara. Pembinaan dapat mengubah perilaku terpidana agar sadar akan hukum. Dengan dijatuhkannya hukuman pidana kerja sosial, maka terpidana akan tidak terkena dampak negatif yakni stigmatisasi oleh masyarakat, serta tidak menanggung malu akibat dirinya pernah menjadi narapidana, selain itu terpidana dapat memetik pelajaran dari hukuman kerja sosial.

Karakteristik sanksi pidana pada pembahasan diatas dapat juga disebut sebagai hukum sanksi. Konsep tersebut berlaku ketika hakim memutus terpidana tersebut dengan hukum sanksi maka perkara pelanggarannya selesai. Apabila terpidana yang belum dijatuhi hukum sanksi, maka penyelesaian perkara pelangarannya belum selesai, meskipun korban telah melakukan ganti kerugian. Model penyelesaian penjatuhan sanksi pidana dengan menggunakan sanksi pidana penjara sangat tidak mengedepankan sisi kemanusiaan dalam hukum pidana. Maka dari itu dalam Draft RUU KUHP 2017 disusunlah alternatif sanksi pidana. Alternatif sanksi pidana dalam Draft RUU KUHP 2017 seperti pidana pengawasan, kerja sosial, pembayaran ganti rugi, dan pemenuhan kewajiban adat. Ketentuan alternatif sanksi pidana menurut draf RUU KUHP 2017 adalah sebagai berikut menurut Pasal 88 RUU KUHP 2017, “pidana kerja sosial dapat dijatuhkan dalam hal :

1. Hakim mempertimbangkan akan menjatuhkan pidana penjara yang tidak lebih dari enam bulan. Dengan demikian, dalam hal hakim mempertimbangkan untuk menjatuhkan pidana penjara lebih dari enam bulan, maka pidana kerja sosial tidak dapat dijatuhkan. Ketentuan ini didasarkan pada falsafah bahwa pidana kerja sosial memang merupakan alternatif dari pidana perampasan kemerdekaan jangka pendek.

1 Agus Rahardjo,"Mediasi Sebagai Basis Dalam Penyelesaian Perkara Pidana”, MIMBAR HUKUM Volume 20,Nomor 1 Febuari 2008 
2. Hakim mempertimbangkan akan menjatuhkan pidana denda dengan tidak melebihi kategori atau maksimum seratus lima puluh ribu rupiah."

Berdasarkan kajian diatas terlihat bahwa ada perbedaan dalam pidana pokok pada KUHP dan RUU KUHP Tahun 2017 tersebut terdapat hukuman alternatif, sedangkan KUHP saat ini tidak ditemukan sanksi pidana alternatif. Namun, yang menjadi subjek untuk dibahas disini adalah penerapan sanksi alternatif tersebut.

Pemidanaan adalah hukuman yang diberikan oleh hakim untuk menghukum terpidana atas pertanggungjawaban dari perbuatannya dengan tujuan menimbulkan efek jera. Pemidanaan merupakan proses penjalanan hukuman dan pembelajaran bagi narapidana agar tidak melakukan tindak pidana lagi. Tujuan utama sanksi pidana dilakukan agar supaya terpidana yang telah terbukti secara sah di pengadilan tidak lagi melakukan tindak pidana dan agar masyarakat luas segan dalam berbuat tindak pidana serupa. Selain itu sanksi pidana juga merupakan sarana balas dendam kepada terpidana oleh korban atas perbuatan yang telah dilakukan oleh terpidana.

Dewasa ini aparatur penegak hukum mengalami masalah yaitu peningkatan kejahatan, sebagian besar dari semua kejahatan-kejahatan terus bertambah dan terus berkembang. Hukuman penjara justru mengajarkan kejahatan oleh penjahat kepada penjahat lainnya. Lembaga Pemasyarakatan (LAPAS) malah berfungsi sebagai tempat pendidikannya para penjahat yang akan melahirkan penjahat yang lebih terlatih. Dengan bermunculannya para penjahat yang lebih terlatih ini membawa dampak yang merugikan bagi warga negara dan negara dikarenakan kejahatan menurunkan moral bangsa ${ }^{2}$. Sanksi penjara juga membawa dampak buruk karena sesama narapidana justru saling melukai dan membawa dampak stigmanisasi yaitu terkucilkan oleh masyarakat dikarenakan merupakan mantan narapidana. Dampak negatif lainnya adalah mantan narapidana tersebut bukannya malu atau menyadari tindak pidananya tetapi malah lebih berani dalam melakukan kejahatan lainnya.

Pada saat ini, bangsa Indonesia beserta negara-negara lainnya telah menggagas pidana alternatif dan menghindarkan pidana penjara. Usaha merumuskan alternatif pidana perampasan penjara berlawanan dari realita bahwa pidana penjara semakin tidak disukai baik pertimbangan ekonomis, pertimbangan humaniter, maupun pertimbangan filosofis.

Dari thesis tersebut kemudian dijabarkan menjadi dua breakdown. Pertama, penulis akan menjabarkan pidana kerja sosial perlu diterapkan di Indonesia. Kedua, penulis akan menjelaskan peran sosiologi hukum dalam penerapan pidana kerja sosial. Metode penelitian yang digunakan penulis dalam penelitian ini adalah penelitian normatif yaitu penelitian untuk menemukan suatu aturan hukum, prinsip-prinsip hukum, maupun doktrindoktrin hukum guna menjawab isu hukum yang dihadapi. ${ }^{3}$ Penelitian ini merupakan penelitian yang mengkaji studi dokumen, yakni menggunakan berbagai data sekunder seperti peraturan perundang-undangan, keputusan pengadilan, teori hukum, dan pendapat para ahli. Penelitian normatif menggunakan analisis kualitatif yakni dengan menjelaskan data-data yang ada dengan kata-kata atau pernyataan bukan dengan angka-angka. ${ }^{4}$ Jenis

2 Muhammad Fajar Septiano „"Pidana Kerja Sosial Sebagai Alternatif Pidana Penjara Jangka Pendek”,Student Journal Universitas Brawijaya,hal. 8

3 Peter Mahmud Marzuki, Penelitian Hukum, Cet.6, (Jakarta: Kencana Prenada Media Group, 2005), hlm. 3

4 Soerjono Soekanto, Pengantar Penelitian Hukum, Penerbit Universitas Indonesia-UI Press cetakan ke-3 tahun 1984, hlm 54. 
data yang penulis gunakan dalam penelitian ini adalah data sekunder. Publikasi mengenai hukum meliputi buku-buku teks, kamus hukum, jurnal hukum, dan komentar atas putusan pengadilan. Teknik pengumpulan bahan hukum yang digunakan dalam penelitian ini adalah studi pustaka. ${ }^{5}$

\section{B. Pembahasan}

\section{Pidana Kerja Sosial Perlu Diterapkan di Indonesia}

Hukum yang baik adalah hukum yang memenuhi rasa keadilan, kemanfaatan dan kepastian bagi masyarakat. Tetapi dalam pelaksanaan hukum pidana Indonesia belum memenuhi tiga unsur tersebut dalam penerapannya. Hukum pidana di Indonesia lebih memihak kaum masyarakat elit daripada kaum masyarakat kelas bawah. Rasa keadilan, kemanfaatan dan kepastian dalam Hukum Pidana di Indonesia seolah-olah dapat dibeli dengan uang oleh kaum masyarakat elit. Agar hukum pidana di Indonesia berjalan efektif memenuhi tiga unsur tersebut maka diperlukan peninjauan kembali dalam pembuatan hukum dan peraturan perundang-undangan. Selain itu diperlukan kerjasama antara aparat penegak hukum dan masyarakat. Aparat penegak hukum berperan untuk menjaga integritas, kredibilitas dan transparasi dalam pemberlakuan hukum pidana di Indonesia. Sedangkan masyarakat perlu mentaati tatacara pemberlakuan hukum pidana di Indonesia. Dengan adanya kerja sama antara masyarakat dan penegak hukum akan menimbulkan rasa kepercayaan yang bersinergi bagi keduanya yang menumbuhkan supermasi hukum di Indonesia. Penjatuhan sanksi pidana yang sering diterapkan dalam hukum pidana Indonesia adalah pidana penjara. Pidana penjara seringkali diterapkan dalam penjatuhan sanksi bagi pelaku kejahatan karena dinilai efektif memberikan efek jera.

Berdasarkan Barda Arief Nawawi, terdapat kritik yang kontemporer terhadap pidana penjara dapat dibagi menjadi dalam 3 kategori yaitu kritik dari sudut strafmodus, kritik dari sudut strafmaat dan kritik dari sudut straftshort. ${ }^{6}$ Kritik dari straftmodus membahas berdasarkan pelaksanaan pidana penjara, yang dapat dilihat berdasarkan cara pembinaan dan institusinya. Selanjutnya, kritik dari sudut strafmaat membahas berdasarkan durasi pidana penjara, terkhusus bagi pihak yang ingin mengurangi durasi atau membatasi pelaksanaan pidana penjara. Kritik dari sudut straftshort membahas penjatuhan atau penggunaan pidana penjara berdasarkan jenis pidana, yaitu harapan agar hakim dalam menjatuhkan pidana penjara lebih selektif.

Disisi lain, pidana penjara masih dibutuhkan untuk sanksi tindak pidana tertentu, yaitu tindak pidana yang berat. Dasar dari pendapat tersebut berdasarkan pada pertimbangan resolusi kedelapan kongres PBB ke-enam mengenai "Alternatives to Imprisonment". Pada pertimbangan kesepuluh tentang "Development of measures for the social resetlement to imprisonment", yang secara garis besar menyatakan bahwa memang diperlukan pidana alternatif tetapi pidana penjara juga masih dibutuhkan dalam beberapa tindak pidana yang dinilai berat. $^{7}$

5 Soerjono Soekanto, dan Sri Mamudi, penelitian hukum normative suatu tinjauan singkat, Jakarta, Raja Grafindo Persada, 2003, hlm.23

6 Barda Nawawi Arief, Bunga Rampai Kebijakan Hukum Pidana (Perkembangan Penyusunan Konsep KUHP Baru), Kencana Prenada Media Group, 2010. Hlm. 132

7 Barda Nawawi Arief, Kebijakan Legislatif dalam Menanggulangi Kejahatan dengan Pidana Penjara, UNDIP, 2002, 
Pertimbangan lain penggunaan sanksi pidana kerja sosial adalah banyak Lembaga Pemasyarakatan (Lapas) yang mengalami over capacity (kelebihan kapasitas), hal ini dikarenakan bertambahnya narapidana di seluruh wilayah Indonesia. Menurut data Direktorat Jenderal Pemasyarakatan (Ditjenpas), per Januari 2019, kelebihan kapasitas di seluruh lapas di Indonesia mencapai angka $101 \% .{ }^{8}$ Oleh sebab itu diperlukan sebuah alternatif bagi pelaksanaan pemidanaan di Indonesia agar sistem pemidanaan Indonesia dapat berjalan dengan baik

\section{Peran Sosiologi Hukum dalam Penerapan Pidana Kerja Sosial}

Menurut Roscoe Pound sosiologi hukum berperan memberikan unsur social psikologi dalam penerapan perintah hukum. Apabila unsur psikologi tidak terpenuhi dalam suatu perintah hukum maka kaidah-kaidah dan undang-undang tidak dapat ditegakan. ${ }^{9}$

Menurut Prof Wijono Prodjodikoro hukum tumbuh berdasarkan nilai-nilai masyarakat. Karena hukum berasal dari nilai-nilai dari masyarakat maka hukum harus disesuaikan untuk membentuk moral perbuatan manusia sesuai dengan norma yang terdapat dimasyarakat. Apabila masyarakat tidak mentaati peraturan hukum maka dapat dikatakan hukum tersebut telah mati. ${ }^{10}$

Begitu pula dalam penjatuhan hukuman pidana. Aliran hukum Barat Klasik mempunyai konsep bahwa hakim sebatas menjalankan perintah undang-undang sehingga dalam menjatuhkan hukuman hakim tersebut tidak melihat faktor-faktor di luar hukum, seperti nilai ekonomi, kultur, moral, agama dan lain sebagainya. Sedangkan aliran realisme hukum sebaliknya hakim dianggap sebagai sumber hukum sehingga dalam menjatuhkan hukuman hakim melihat faktor-faktor diluar hukum seperti nilai ekonomi, kultur, moral, agama dan lain sebagainya.

Seiring berjalannya waktu, banyak negara-negara yang mulai mengadopsi pemikiran bahwa hukum harus tumbuh dari nilai-nilai yang berkembang di masyarakat. Hukum diciptakan dan didasarkan untuk dan oleh komunitas masyarakat sehingga hukum tak harus menyertai dan melihat faktor-faktor sosiologis. "Di Barat sendiri juga terus terjadi perubahan yang tak terelakkan. Paradigma legalistik Barat Klasik tersebut telah diubah di Amerika Serikat sejak tahun 1950-an di masa reformasi peradilannya, menjadi paradigma social justicedi masa hakim agung Holmes, Cordozo, Llewellyn, Frank, Gray dan lain-lain. Jadi, reformasi peradilan yang teramat penting adalah reformasi paradigma." Hal ini termasuk pula dalam penjatuhan sanksi pidana yang harus sesuai dengan nilai-nilai yang ada di masyarakat.

Persis dengan adat istiadat Indonesia yang berlandaskan ideologi pancasila sebagai sumber dari segala sumber hukum di Indonesia, yang mana sesuai dengan sila kelima berupa "keadilan sosial bagi seluruh rakyat Indonesia." Masyarakat Indonesia mengharapkan hukuman pidana yang berdasarkan atas cita-cita masyarakat Indonesia yang dapat berguna bagi bangsa dan masyarakat Indonesia. Pidana kerja sosial sudah tepat dengan kultural masyarakat Indonesia karena melakukan kegiatan yang dapat

Semarang, Hlm. 43

8 Ibid. hlm. 238.

9 Roscoe Pound, The Task of Law (Tugas Hukum), terjemahan Muhammad Radjab, Bhratara, Jakarta, 1965. Hlm. 66

10 R. Wirjono Prodjodikoro, Asas-asas Hukum Perdata, Bale Bandung, Bandung, 1988, Hlm.154 
membantu dalam mengadakan sarana dan prasarana umum yang nantinya akan berguna bagi khalayak umum. Pidana kerja sosial memegang nilai perlindungan dari kekejaman sesama narapidana di penjara yang terkenal dengan tindakan kriminalnya. Pidana kerja sosial juga sesuai dengan kebudayaan bangsa Indonesia yaitu melakukan kegiatan yang menguntungkan masyarakat umum tanpa mengejar upah atau biaya atas pekerjaan yang dilakukannya. Keuntungan pidana kerja sosial lainnya adalah para narapidana akan dibimbing dan dibina agar karakter mereka sesuai dengan nilai-nilai yang berlaku di masyarakat. Dengan pidana kerja sosial, kemungkinan terpidana melakukan tindak pidana lagi akan sangat kecil kemungkinannya, hal ini dikarenakan jika terpidana sebelumnya sudah melakukan pidana kerja sosial maka apabila mendapat hukuman lagi maka terpidana akan dikenakan pidana penjara dan atau denda dan tidak akan menjatuhkan kembali pidana kerja sosial.

Berdasarkan ketentuan Pasal 88 RUU KUHP 2017, pidana kerja sosial dapat dijatuhkan dalam hal :

a. Hakim mempertimbangkan akan menjatuhkan pidana penjara yang tidak lebih dari enam bulan. Dengan demikian, dalam hal hakim mempertimbangkan untuk menjatuhkan pidana penjara lebih dari enam bulan, maka pidana kerja sosial tidak dapat dijatuhkan. Ketentuan ini didasarkan pada falsafah bahwa pidana kerja sosial memang merupakan alternatif dari pidana perampasan kemerdekaan jangka pendek.

b. Hakim mempertimbangkan akan menjatuhkan pidana denda dengan tidak melebihi kategori atau maksimum seratus lima puluh ribu rupiah.

Sementara itu, berdasarkan ketentuan Pasal 88 Ayat (2) RUU KUHP 2017 dinyatakan, dalam hal hakim akan menjatuhkan pidana kerja sosial perlu diperhatikan berbagai hal. Berbagai persyaratan tersebut dimaksudkan agar pidana kerja sosial benarbenar dapat dijalankan. Tentu saja tidak semua perbuatan pidana dapat dikenakan atau diberikan pidana kerja sosial, adapun kriteria dalam penjatuhan sanksi dalam pidana kerja sosial adalah sebagai berikut :

a. Pidana kerja sosial dapat dijatuhkan kepada terdakwa yang melakukan tindak pidana yang diancam dengan pidana penjara di bawah lima tahun dan hakim menjatuhkan pidana tidak lebih dari enam bulan penjara atau pidana denda tidak lebih dari Kategori I.

b. Dalam penjatuhan pidana kerja sosial sebagaimana dimaksud di atas, wajib dipertimbangkan hal-hal sebagai berikut :

1) Pengakuan terdakwa terhadap tindak pidana yang dilakukan;

2) Usia layak kerja terdakwa sesuai dengan ketentuan peraturan perundangundangan;

3) Persetujuan terdakwa sesudah dijelaskan mengenai tujuan dan segala hal yang berhubungan dengan pidana kerja sosial;

4) Riwayat sosial terdakwa;

5) Perlindungan keselamatan kerja terdakwa; 
6) Keyakinan agama dan politik terdakwa; dan

7) Kemampuan terdakwa membayar pidana denda.

c. Pelaksanaan pidana kerja sosial tidak boleh dikomersialkan.

d. Pidana kerja sosial dijatuhkan paling lama :

1) Dua ratus empat puluh jam bagi terdakwa yang berusia delapan belas tahun atau lebih; dan

2) Seratus dua puluh jam bagi terdakwa yang berusia di bawah delapan belas tahun.

3) Pidana kerja sosial sebagaimana dimaksud pada poin tiga, paling singkat dilaksanakan selama tujuh jam.

4) Pelaksanaan pidana kerja sosial dapat diangsur dalam waktu paling lama dua belas bulan dengan memperhatikan kegiatan terpidana dalam menjalankan mata pencahariannya dan/atau kegiatan lain yang bermanfaat.

5) Jika terpidana tidak memenuhi seluruh atau sebagian kewajiban menjalankan pidana kerja sosial tanpa alasan yang sah, maka terpidana diperintahkan:

a) Mengulangi seluruh atau sebagian pidana kerja sosial tersebut;

b) Menjalani seluruh atau sebagian pidana penjara yang diganti dengan pidana kerja sosial tersebut; atau

c) Membayar seluruh atau sebagian pidana denda yang diganti dengan pidana kerja sosial atau menjalani pidana penjara sebagai pengganti pidana denda yang tidak dibayar."11

Namun, yang menjadi kekurangan dalam pidana kerja sosial adalah tidak diaturnya minimal berapa jam dalam sehari seseorang terpidana harus melakukan pidana, serta tidak adanya suatu pengawas seperti supervisor yang bertugas mengawasi jalannya pidana ini. Apabila dibandingkan dengan negara Inggris ada supervisor yang mengawasi jalannya pidana ini. ${ }^{12}$

\section{Kesimpulan}

Pelaksanaan Hukum Pidana di Indonesia sering kali menggunakan model sanksi pidana penjara. Namun seiring dengan perkembangan zaman sanksi pidana penjara dinilai tidak mengedepankan sisi kemanusiaan bagi pelaku kejahatan. Maka dari itu diperlukan alternatif sanksi yang lebih mengedepankan sisi kemanusiaan. Alternatif sanksi di buat berdasarkan kongres PBB keenam mengenai "Alternatives to Imprisonment". Pada pertimbangan kesepuluh tentang "Development of measures for the social resetlement to imprisonment", yang secara garis besar menyatakan bahwa memang diperlukan pidana alternatif tetapi pidana penjara juga masih dibutuhkan dalam beberapa tindak pidana yang dinilai berat. Karena hal tersebut Pemerintah Indonesia dalam Draft RUU KUHP 2017 menyusun

11 Rizqi Aminulloh Ibrahim, "Gagasan Sanksi Pidana Kerja Sosial (Community Service Order) Terhadap Terpidana Korupsi Prospektif Teori Analisis Ekonomi Mikro Dalam Hukum Pidana” (Yogyakarta : UII, 2019), Hal.52-54.

12 Legislation.gov.uk., The Community Service Orders Rules 1989, (diakses pada tanggal 20 Desember 2020), URL: http:// www.legislation.gov.uk/uksi/1989/191/article/1/made. 
beberapa alternatif sanksi salah satunya sanksi pidana kerja sosial. Sanksi pidana kerja sosial dari segi sosiologi hukum menurut pandangan Roscoe Pound dalam penerapannya dinilai telah memenuhi aspek sosial psikologis bagi pelaku kejahatan.

\section{Daftar Pustaka}

\section{Sumber Buku :}

Barda Nawawi Arief, Bunga Rampai Kebijakan Hukum Pidana (Perkembangan Penyusunan Konsep KUHP Baru), Kencana Prenada Media Group, 2010.

Barda Nawawi Arief, Kebijakan Legislatif dalam Menanggulangi Kejahatan dengan Pidana Penjara, UNDIP, 2002.

Muhammad Fajar Septiano, Pidana Kerja Sosial Sebagai Alternatif Pidana Penjara Jangka Pendek, Student Journal Universitas Brawijaya.

Peter Mahmud Marzuki, Penelitian Hukum, Cet. 6, Jakarta : Kencana Prenada Media Group, 2005

Soerjono Suekanto, Pengantar Penelitian Hukum, Penerbit Universitas Indonesia-UI Press cetakan ke-3 tahun 1984.

Soerjono Soekanto, dan Sri Mamudi, penelitian hukum normative suatu tinjauan singkat, Jakarta, Raja Grafindo Persada, 2003.

R. Wirjono Prodjodikoro, Asas-asas Hukum Perdata, Bale Bandung, Bandung, 1988.

Rizqi Aminulloh Ibrahim, “Gagasan Sanksi Pidana Kerja Sosial (Community Service Order) Terhadap Terpidana Korupsi Prospektif Teori Analisis Ekonomi Mikro Dalam Hukum Pidana" (Yogyakarta : Uii, 2019).

Roscoe Pound, The Task of Law (Tugas Hukum), terjemahan Muhammad Radjab, Bhratara, Jakarta, 1965.

\section{Jurnal}

Agus Rahardjo,"Mediasi Sebagai Basis Dalam Penyelesaian Perkara Pidana", MIMBAR HUKUM Volume 20, Nomor 1 Febuari 2008.

\section{Sumber Web}

Legislation.gov.uk., The Community Service Orders Rules 1989, (diakses pada tanggal 20 Desember 2020), URL:http://www.legislation.gov.uk/uksi/1989/191/article/1/mad 